\title{
Survival and Sovereignty: Forces on the Rise in Aurelio Tolentino's Novels
}

\author{
Loida L. Garcia \\ Associate Professor, Bataan Peninsula State University, \\ Dinalupihan Campus, Bataan, Philippines; Associate Member, NRCP \\ llgarcia@bpsu.edu.ph
}

\begin{abstract}
Aurelio Tolentino (1869-1915) is best remembered as the first nationalist dramatist who was in and out of prison because of his mutinous writings. His five extant novels manifest the sociopolitical struggle of early 2oth-century Filipinos from the worldview of a versatile author. Tolentino's fiction from 1909 to 1914 unveils how the colonized adapted ingrained, rigid, and conventional Spanish influences to the liberal and materialistic scheme imposed by the United States. A sociohistorical approach was used to investigate Tolentino's narratives, revealing a people with a pliant but firm character brought about by their four centuries of subjugation. The literary method used in the study likewise illuminates the economic and literary struggles of the author as an ex-convict. The novels illustrate how the suppressed survived and yearned for sovereignty from the dual domination that beset the land.
\end{abstract}

\section{Keywords}

Aurelio Tolentino - dual dominion - extant novels - Kapampangan - sociohistorical

\section{Introduction}

Global and regional studies of literature have always been a fascinating field that discloses the connections of a race's past, present, and future. The present generation is always a recipient of historical and societal phenomena that took place before them. Aurelio Tolentino's fiction, set in the Philippines, illustrates a distinct identity that resembles the dynamic social, political, and 
other institutional forces of a nation. The author and his novels, in the same breath, caution his readers on what may occur and what measures should be employed. His narratives and verse disclose to present-day readers actual scenarios after Spain turned over the country to the United States. Tolentino's themes are universal, for they speak of mankind's instincts for survival and the pursuit of sovereignty.

Studies that are geared toward literature, arts, history, and culture are priority areas called for by the National Higher Education Research Agenda of the Commission on Higher Education (CHED) in aid of national and regional development. The approved Harmonized National Research and Development Agenda of the National Research Council of the Philippines has included in their 2017-2022 priority areas the Filipinnovation of literature. By this, the campaign seeks to make some significant changes and discoveries in the field of literature. Moreover, the current pioneering attempt to recognize and revive Aurelio Tolentino's novels is presumed to elicit studies that may address the lack of literary materials in vernacular settings. The K-12 curriculum of the Department of Education (DepEd) in the Senior High School mandates the teaching of $21 s t$ Century Literature from the Philippines and the World. This campaigns for the appreciation and critical study of regional literature in school. As directed by the program, the stated core subject considers various dimensions of Philippine literary history from pre-colonial to contemporary times. Likewise, it requires a consideration of the background of early authors and their works.

Aurelio V. Tolentino (1869-1915) was a remarkable writer-activist whose nationalism is greatly embedded in his writings. His works easily surpass those of his contemporaries during the first two decades of the 2oth century, particularly in novel writing. His prominence as a playwright is enshrined at the Little Theater of the Cultural Centre of the Philippines (CCP), which is named Tanghalang Tolentino (Tolentino Theatre). In 2017, the CCP staged the zarzuela entitled Aurelio Sedisyoso (Seditious Aurelio) that showcased Aurelio Tolentino's life primarily as a fiery freedom fighter. Tolentino is hailed as a nationalistic patriot whose works in varied genres ultimately urge his readers to recognize the reality of their present colonial woes.

Much has been written about Tolentino, but surprisingly, scholars have not settled on the exact date of his birth. During the early '8os, Tolentino's birthday was given as October 15,1875 , not October 13,1867 , as previously recorded in the '7os. However, the National Historical Commission of the Philippines (NHCP) held on to the old record and commemorated the 15oth anniversary of Tolentino's birth in 2017 at his birthplace in Guagua, Pampanga. The issue of Tolentino's birthdate was given another twist when renowned historian-curator 
Ambeth Ocampo (2019) has attested to the unpublished handwritten autobiography of Aurelio Tolentino dated 1908. In the newspaper publication, Ocampo disclosed that Tolentino was born on October 15, 1869. Historians and literary scholars, though, have unanimously recorded his premature death in July 1915.

The handwritten autobiography, originally written in Spanish, not only eliminates the inconsistencies surrounding Tolentino's birthdate but confirms the quest for sovereignty that defined the author's life. In the English translation by Ocampo in 2019, Aurelio Tolentino's concluding statement was: "Here is a synthesis of my sad life, full of worries, torture, misery, and sufferings." The personal account of Tolentino is a narrative of a man whose dream from his youth had been to seek liberation from foreign rule. He was engaged in the armed struggle against Spain, followed by his court disputes versus the United States. He learned to survive in his colonized society not only as a revolutionary but as a writer and journalist as well.

Tolentino's autobiography declares his path to survival and goal for sovereignty. In 1891, he was forced to quit law school because of his father's death. A year later, he became a member of the anti-Spanish revolutionary society Kataastaasa't Kagalanggalang na Katipunan ng manga Anak ng Bayan (K KK) recently founded by the celebrated hero Andres Bonifacio. He was actively engaged in the initiation and recruitment of members to liberate the country through guerilla warfare. On the walls of Pamitinan Cave in Rizal, Tolentino inscribed these words: "Viva la Independencia de Filipinas!"

From 1896 to 1907 , bearing the wrath of both Spain and the United States, Tolentino was in and out of prison. He was arrested for being a Katipunero (revolutionist), as a Mason, and for his subversive writings, and he was consistently charged with treason. His education as a law student prepared him to work on his continuous appeal for a pardon, but these efforts cost him a huge amount of money. His autobiography recounts the torture he suffered, which, however, did not induce him to succumb to the colonizers. He kept on connecting with insurgent patriots and, in 1904, formed a new revolutionary dictatorial government where he was unanimously elected as the head or dictator. He was later arrested and sentenced to six years in prison and hard labor plus a fine of more than USD 5,000.00, a massive sum at that time. On February 5, 1907, Tolentino was released on parole but was required to report regularly to the authorities for the next five years.

Given his miseries, Tolentino had to find means to support himself yet never let go of his ultimate goal to seek sovereignty for the country. As a newspaperman constantly detained for his subversive articles, he wrote: "I was convinced that it was impossible to live the life of a journalist." Hence, he shifted focus, writing zarzuelas, dramas, melodramas, and stage plays. A true guerilla, 
Tolentino had seen and embraced a new glimpse of hope. He would use contemporary forms of writing to communicate with his readers. His novels would later be a means of financial survival and a platform for his political advocacy.

\section{Literature Review}

Studies on local novels have dimmed significantly over the years. Researchers have largely lost interest in investigating the genre primarily because of a lack of available full copies of materials. A cursory examination of literary journals makes clear that scholars have shown more interest in delving into world masterpieces than homegrown writing. Dolefully, research on regional poetry, zarzuelas, plays, and folksongs that had once been favored about four decades ago had been set aside. Although books on Kapampangan literature and anthologies were published in the '8os, very few studies were geared toward novels, and none was focused solely on Aurelio Tolentino's novels. The recurrent dilemma is that scholars are hampered by their inability to recover century-old manuscripts; hence, it is not startling that Kapampangan novels remain an unexplored field.

It was only in 1973 that the heirs of Aurelio Tolentino donated volumes of his works to the University of the Philippines Library. After two years, a book about his life and writings was published, but full copies of his novels remained unavailable. Fortunately, Project Gutenberg digitized some of his works, and two of his novels have been available since 2013. In 1955, a study about Tolentino's novel Ang Buhok ni Ester was conducted as an unpublished master's thesis. It did not prompt follow-up studies about Tolentino's other novels but, at least, Kapampangan works that were scrutinized in future studies often cited and included the author's narratives.

Lalas-Garcia, from the same town as Tolentino, initiated the most recent study on Kapampangan novels in her 2018 published dissertation, focusing on the sources and influences of the stated local fiction. The investigation covered all vernacular novelists and their works, stimulating a more in-depth analysis of each of the Kapampangan novelists. The study of Tolentino's works was warranted because of his distinct personality as a nationalist writer aside from bequeathing more volumes to the early novel genre. In contrast to the wider perspective employed in Lalas-Garcia's study of Kapampangan novels, the present study exclusively deals with the literary landscape that prompted Tolentino to produce his popular fiction.

In 2017, Garcia initially introduced Aurelio Tolentino as a novelist in her paper titled The Hispanic Culture of Kapampangan Novels, which explored the 
influence of Spain on the writer's characters and contexts. She strongly suggested that there be succeeding studies that would focus on the socio-cultural and political aspects of Tolentino's novels. The present study explores the need for survival and the quest for sovereignty that are recurrent in all of Tolentino's novels. The conditions during the subjugation of Spain and the United States are inevitably reflected in the fiction. The message of the author more than a century ago can still be heard by contemporary readers. It is a zealous entreaty for literary scholars to communicate with the author by looking deeply at his texts.

Academic works relative to the genre that portray the colonial attitude of early Filipinos leave much to be desired. Usually, authors who indulged in this kind of critique center their insights into character development. Patterson, in 2014, explored Pacho's novel Cebu about a Filipino-American priest on his first trip to the Philippines to bury his deceased mother. The essay focuses on the work's social satire, exposing how the ideologies of liberal tolerance affect Filipino-Americans. It is disclosed that the novel searches for the social reciprocity that migrants pay back their homeland and the host country. The present paper likewise examines the cultural aspects of Tolentino's novels. Based on biographical accounts, the author participated in multiple ground battles in his advocacy to liberate the country from colonial rule. His novels are likely to serve as his platform to connect with his readers.

Meanwhile, the study authored by Baldoz and Ayala and published in 2013 emphasized how US policies toward the Philippines and Puerto Rico affected the locals. The mode in which these policies created a great impact on the social conditions of the people yielded civil conflicts as the colonizers attempted to impose policies that were inappropriate to the contemporary state of mind of the colonized. The existing study also considers the age of US imperialism, which was a repeated theme in Tolentino's extant novels. In addition, the power the United States exerted over the natives is manifested by the author as a complete betrayal of the Filipino people. The colonial policy on liberalism benefited only the upper class, while the poor sank further into poverty.

In terms of a local novel review, the most relevant is the critique of StuartSantiago (2000) on the award-winning novel of Gamalinda published in the same year. The novel My Sad Republic (2000) explores the Filipino-American war and the agony and humiliation of the powerless at the hands of Spain and the United States. The novel depicts the disgrace of capitulating to the American promise of liberalization. This relates to Tolentino's narratives that greatly represent the shame of being subjected to foreign rule. Tolentino compared the United States to King Samuel, one of the main characters in his novel 
Yesterday, Today and Tomorrow (1913), who misled the Filipino natives under his guise of friendship.

The current study is focused on the thesis that Aurelio Tolentino produced the greatest number of Kapampangan novels primarily because of his need for survival and advocacy for national sovereignty. The novels are analyzed as a whole based on their contextual setting, not limited to any literary elements such as forms or structures but on how they existed during his time, as prompted by conditions at the onset of the 2oth century. The investigation of the novels is centered on the sociohistorical and cultural conditions that paved the way for Tolentino's fictions.

The writer employs the combined historical and sociological methods of literary criticism to answer the research inquiries. This scheme is found to be the most appropriate framework for the study, as it provides the needed background for scrutinizing the novels. A diachronic analysis of his works is also found essential on the basis that the novels did not exist in isolation but as a product of a prevailing phenomenal condition.

The novels of Aurelio Tolentino exude his need for survival and mission for sovereignty, and this is manifested through the sociohistorical approach. His life and works are stamped with his character as a guerilla fighter, a daring journalist, and a versatile writer. How he was able to survive and ceaselessly called for sovereignty was inevitably embossed in his novels. His short life from 1869 to 1915 reveals much about Filipino life under Spain for more than three centuries and later followed by the American rule. Tolentino fought on the battlefield to topple Spain, and then the American soldiers. Notwithstanding, the US took control in 1900 after the Spanish downfall. Another colonial lord has taken over the land that the patriots have tried so hard to regain.

Ehrman (2014) explains that through the sociohistorical approach, the author's experiences and his social group would have affected the presentation of the material. The approach is centered on the relationship between a literary text and the social history of its author and the community. It is surmised that Tolentino produced his works based on the actual social and historical contexts of his time. Further, it is through the author's perception of reality that he formed his judgment and used art as his podium for expressing it. Through the historical-sociological method of research, the milieu of Tolentino's novels - the context of their publication and the author's worldview as predisposed by the conditions during his lifetime-is explored. Remarkably, the 
publication of Tolentino's first novel Buhay in 1909 took place after repeated detentions and parole, which consequently cost him a fortune.

As cited by Lalas-Garcia (2018, 23), Reyes (1992), in her book Kritisismo, details the sociological and historical concepts of literary criticism in the country. Reyes states that critics will establish a broader perception of local texts if they adopt a historical perspective that takes readers into the past when the literary form started. Once the critics lay down the historical and sociological contexts of the works, it is easier to understand why certain literary genres developed and flourished in different stages. Reyes further attested to the appropriateness of the methodology when she employed the method in her dissertation Kasaysayan at Kontekstong Panlipunanng Nobelang Tagalog, 19051975, published in 1979. In the same investigation, Reyes centered her study on 310 Tagalog novels using the historical/sociological concept. She found that the use of this combined approach affirmed the concept that Tagalog novels of 70 years were created based on the authors' subjective interpretation. Their perception is influenced by the existing condition of their time and on how they perceived reality.

Ian Watt (1957, 16), a French-Scottish critic, in his book The Rise of the Novel, asserts that the plot in the novels had to be acted by particular people in particular circumstances. By this, he explored the influences of social situations in novels by Daniel Defoe, Samuel Richardson, and Henry Fielding, who were affected by changes in the reading public of their time during the 18th century and whose works were conditioned by new social and moral conditions, which the novelists and their readers shared.

From the cited concepts, the five extant novels of Tolentino, in the same manner, are best explored using a sociological approach in literary criticism on the basis that the works are grounded in the contemporary circumstances of the time of their first publication, in 1909, the first decade of US rule when people became either passive or indifferent to the colonial mechanism. Until the publication of his last novel in 1914, Tolentino's novels illustrate not only his sentiments but the emotions of the people in that particular period as represented by the characters. The cultural conditions, which include the social, economic, political, and other aspects of 2oth-century life, were disclosed. Tolentino has become the best representative of a reality that speaks from his active involvement as a guerilla in warfare and a journalist using his narratives to connect with his readers. The study aims to gain a better understanding of how his novels were produced, how they were influenced by the specific contextual setting of their time, and why survival and sovereignty are the forces that impelled the writing of his novels. 
Aurelio V. Tolentino was a product of the three-century rule of Spain and the forceful takeover of the US. He was a distinguished and educated man who personally struggled against colonizers not only through his journals but also via armed revolution. Fluent in three languages: Spanish, Kapampangan, and Tagalog, he produced theatrical works such as plays, zarzuelas, and dramas, aside from other fiction, moralistic works, and newspaper articles. He spent all his life mostly on writing and fighting for a patriotic cause. Aside from working as a notary public, government functionary, and teacher, Tolentino was also a pro-labor advocate who fought for the rights of workers. Despite having accomplished so much, Tolentino, in his autobiography, states, "My life story is poor and unhappy." True enough, the underlying impact of the need for survival and the quest for sovereignty is evident in his life and works.

\subsection{Tolentino's Literary Survival}

The first decade of US rule marked a literary shift from the Spanish-inspired corrido to realistic writing. The new policy on progressivism and liberalism generated interest in the modern-day landscape in terms of literary production. The usual metrical romances and fantasy tales encouraged by Spain were spurned by playwrights in favor of realistic writing. The Spanish plays and corridos were replaced by localized zarzuelas, of which Tolentino authored at least 10. Barely a few years into US rule, the grandeur characteristic of Spanishinfluenced literature in the form of fantasy and make-believe was rebuffed by both local writers and the reading public.

The liberalization policies introduced by the new American rulers led inevitably to innovation in the old genres of writing. The strict and rigid censorship of Spain was replaced by the more lenient and tolerant US policy. More publications, literary organizations, and printing presses ensued, and newspapers published serial stories and novels that gained wide approval. In terms of readership, the early Filipinos benefitted from US educational policy that mandated natives to gain literacy. Larkin $(1972,144)$ reports that the number of students in Pampanga increased from 3,400 (1901) to 13,000 (1910), and the number of schools jumped from 41 to 185 in the same period. There is no wonder that, as early as 1900, fiction in serial form began to be printed, and in 1905, the first Tagalog novel Nena at Neneng was published.

The newspaper El Imparcial in the province of Pampanga followed the trend and published in 1907, the first Kapampangan novel Lidia by Juan Crisostomo 
Soto (1907) in serial form. The new genre was met with an enthusiastic reception; hence, Tolentino, who received his parole in 1907, had to adapt his writing to the latest trend. He developed Mutya, originally written in Kapampangan, into his first Tagalog novel Buhay, released in 19o9. For his literary career to survive, the author had to adapt to the US colonial rule to shun the old Spanishinfluenced writings and refrain from circulating moro-moro, cenaculo, comedia, awit, and other religious writings which he used to publish.

Well acquainted with the rising popularity of novel writing in the West since the 18th century, Tolentino proved that he could go along with the newest literary genre. He was well aware that the realist movement was promising and widely acknowledged. The author had to keep pace, thereby serving two purposes: getting into the modern novel writing and turning it into his advocacy forum.

Tolentino's novels are liberally endowed with "verisimilitude," depicting the current reality of people's lives. They represent varied social and political classes, economic conditions, and the character of the natives. The sentiments of every character embody the personalities in a colonial setting. The use of the Kapampangan and Tagalog languages is particularly striking in that the author, like the realists in the West, used "quotidian" characteristics. The setting, verbal communication, actors, conditions, and even use of the authorial voice were designed by Tolentino to connect with his audience and continue his mission.

\subsection{His Socioeconomic Survival}

Historical accounts state that the US occupation brought about an abrupt social and economic change in Kapampangan society (Larkin 1972, 129). This, in turn, created a separate identity and economic hostilities among the elites and common folk. The landlord-peasant camaraderie during the Spanish rule was influenced by the rapid transformation brought by the new colonial rule. Gradually, landlords became profit-oriented instead of giving their land workers their full trust. The old "familial" relationship was strained; the upper-class landlords became more associated with the American authorities, the Spanish and Chinese mestizos, and the native elites which caused the lower-class peasants to see the huge gap between them. The masses had been discriminated and a growing animosity was established on both sides. Tolentino's novel Ang Buhok ni Ester shows the ideal landlord in the character of Don Luis as fatherly and benevolent in contrast with his greedy and ambitious nephew Gerardo. The peasant characters of the novel portray their thoughts toward them. 
The beginning of the 2oth century saw the Chinese populace greatly increase in number, along with all their wealth, power, and business acumen. They dominated the commercial sector of the province as buyers, exporters, middlemen, as well as workers in all business sectors. They firmly established themselves in the towns of Pampanga, including Guagua, the birthplace, and home of Aurelio Tolentino. It is no wonder that the author vehemently despised the presence of the Chinese, bluntly claiming in his novels that they wanted to own the land that belonged to the Filipinos. The lawyer character of Oscar in Ang Buhok ni Ester shuns provincial officials who prefer Chinese workers to locals for agricultural work because of the low salary paid to them. Oscar reasons that displaced local workers are left demoralized and unemployed while the Chinese continuously flood into all places. Tolentino, through the governor-candidate Ruben, had campaigned for a wise election in the novel to advocate against corrupt candidates who caused suffering to the masses.

Moreover, because of the glaring economic security enjoyed by the Spanish friars and clergy, in addition to the political influence of the local elites under colonial rule, the common people became the downgraded sector. From 1896 to 1901, there was tremendous economic and physical hardship that heavily burdened the lower class. The sugar industry was down to its lowest, crops were affected, livestock was destroyed, and criminals and bandits cropped up as feared when social and economic unrest becomes rampant. "Bandits" are ever-present in Tolentino's novels.

During the first decade of US rule, the time when Tolentino's novels flourished, new American policies brought about drastic reforms in the country. The Americans were short-staffed to implement the new programs, so they relied heavily on native cooperation. A new political structure emerged, which required governors and board members in the province through an election process. The elected leaders became symbols and cradles of political power. The upper-class native elites had the authority to rule over their people, not for the common good but more often for personal gain. The vaudeville and amateur presentations, which common people could not afford to see, were often financed by townspeople or political candidates to use as a platform for campaigns and gain votes during elections. The issue of prudent voting was heavily advocated by Tolentino using his authorial voice in his novels. He condemned crooked politicians and local officials motivated by nothing but self-interest.

The handwritten autobiography of Tolentino clearly states the huge amount of money that he spent to gain his freedom from prison. On February 5, 1907, the author was granted parole on the condition that he presented himself to the authorities every month for five years. Accounts show that after his first 
imprisonment in 1896, he could no longer practice as a notary. On May 4, 1903, he was sentenced to two years of hard labor and a fine of USD 2,000.0o for the crime of sedition. In December of 1903, he was released on bail of PHP 7,000.00. On June 14, 1904, Tolentino was again captured and condemned to six years in prison with hard labor and a fine in excess of USD 5,00o. All this money placed a financial burden on the author, considering that among peasants, the average pay for a hard day's work was roughly only one peso. In Tolentino's novel Maring (1913), as a housemaid, Maring is only paid PHP 8.00 monthly by her American employer. Furthermore, in Ang Buhok ni Ester, a hundred-peso monthly salary for Gerardo as an estate administrator is considered a generous and gallant offer from his employer-uncle. Thus, the amount of money disbursed by Tolentino for his freedom was palpably a massive fortune during his bachelor days.

Based on his autobiography completed in 1908, Tolentino, assumed to have married sometime between 1907 and 1908, opted to leave his birthplace and reside in Manila with his growing family. It was in the seat of government that, together with his brothers, he ventured into a printing press business for economic security. His move was not an isolated case because records show that as early as 1903, over 17,000 Kapampangans had already relocated to Manila. He would find some means to support his family financially, though the patriot in him would not rest. Tolentino attempted to find another forum to awaken the sensibilities and devoted spirit of his people in his call for survival in their yet again colonial state while yearning for their sovereignty.

\section{Tolentino's Extant Novels}

Tolentino's novels under study are (1) Buhay (Buhay), 1909, previously titled Mutya, which was written in Kapampangan; (2) Ing Buac Nang Ester, three parts, 1911-1915, later translated in Tagalog as Ang Buhok ni Ester (Esther's Hair Strand); (3) Maring: Dangal at Lakas (Maria, Honor, and Strength), 1913; (4) Napun, Ngeni at Bukas later translated as Kahapon, Ngayon at Bukas (Yesterday, Today, and Tomorrow), 1913; and (5) Kasulatang Ginto (Golden Inscription), 1914. Tolentino's Tagalog translation of his novels met his aim to get a wider audience.

\subsection{The Need for Survival and Sovereignty}

These five novels share the same recurrent pattern of the concept of survival and sovereignty. His characters plainly show the attitude of the early Filipinos 
and are a manifestation of his patriotic being. The current conditions depicted in the novels disclose what was an ingrained dual colonial influence that seeped into people's consciousness. Because of the three-century Spanish rule ended by US imperialism, the natives yielded to and bore the influences of both powerful invaders. The new colonial lords had yet to rid the locals of the cultural imprint of Spain. The first two decades of US rule exposed Filipinos to liberalization and commercialization as opposed to the conventional and simple living under Spain. For their survival, Filipinos were left with no choice but to witness and accede to the transformation of their society. The deeply rooted drive for sovereignty persisted among the masses, who were perceived as outwardly flexible and compliant to the new rulers. However, the changing circumstances would divide the patriotism of the locals, and personal gains were needed to be addressed to finally attain independence. The symbols used in the novels are eloquent encryptions that Tolentino and his readers instantly shared as proven by their popularity during their releases. As a well-known newspaperman and nationalist, the author found in his fiction a vehicle for forging a strong bond with his audience.

\subsubsection{Buhay (1909)}

The novel highlights the judicial expertise of Tolentino as he describes an elaborate court proceeding to acquit the characters of Buhay and Marcial. His use of symbolism is at once signaled by the novel's title "Buhay," the pet name of Isabel gifted by her mother Dining, which means "life." Buhay is her mother's life. Dining represents the selfless love of a mother, willing to go to any lengths to assure her child's safety. Moreover, Buhay is a manifestation of an ideal child who gladly pays her debt of gratitude to her parent. The readers discern that love for the motherland is Tolentino's spontaneous message. Buhay or "life" is what should be offered to the self-sacrificing motherland. Anyone hesitant to do so is a stranger whose evil motives will soon be revealed. Daluyong, Dining's husband, is not the biological father of Buhay; thus, his self-interest is clearly shown. Daluyong represents the colonizers who do not belong to the motherland and is thus portrayed as a traitor.

Tolentino divulges the impending grief of the main characters, describing the moon as hidden and the wind as having gone mad. Chapter Xx of his novel, subtitled "The Deaf Witness," points to a garment worn by the true culprit in the murder case. Using his authorial voice, Tolentino presents the innocence of the sweethearts, thereby sharing his thoughts to his readers on how the innocent land has been exploited by invaders.

Being a law student, the author provides free legal counsel to his readers. Having been imprisoned on nine occasions, he elucidates in his novel the 
proper justice system that needs to be accorded to people. No one needs to be in jail if innocent of the crime, and everyone has the right to freedom. Buhay and Marcial are victims of circumstance, and they should not suffer needlessly. Dining, despite the threats from her husband, sought the help of the Spanish captain to rescue her daughter. Tolentino explains that this Spaniard has enjoyed the generosity of Dining's old family, so he cannot possibly refuse. Dining, the usually meek and pliant woman, stands up against blackmail, exposes the duplicity in the Spanish friar's personality, and thwarts the plans of evildoers. At last, she comes to the point of betraying her wicked husband for conniving with the victim for his egotistical purposes.

Through his omniscient narration, Tolentino is able to communicate with his readers. The motherland does her best for her children, but she needs love. Just like Buhay, this could only be shown by doing what is needed. It is the duty of all children to prove their gratitude even to the extent of giving their life. His readers are made to understand that it requires a strong will, courage, and even the loss of self-seeking family members to survive in their present situation and win the battle for sovereignty.

5.1.2 Ang Buhok ni Ester (1911-1915)

Ang Buhok ni Ester (Esther's Hair Strand) is considered by literary critics Tolentino's best novel. In this work, he makes effective use of the elements of gothic fiction, such as suspense, fear, horror, and death. The first part of the novel uses varied symbolism from the subtitles to the discourses. The initial chapter in the English translation is titled "Lightning in the House," followed by "Storms in the Heart." The original Kapampangan and Tagalog texts instantly urge his readers to get involved in the turn of events. Tolentino's audience knew that kidlat (lightning) and bagyo (storm) are foreseen as startling disasters that eventually pass in due time. The 333 years of Spanish rule have ended, and the US takeover follows. The author has skillfully created his web of resiliency in his characters, which speaks of pliant people during his time.

The novel's appeal for sovereignty is heavily embossed on all his characters. Don Luis blatantly discloses the ills of society because of corrupt local politicians and the present foreign policy imposed on the country. In his speech, he prompts his audience by saying that "our land is beset by illness and everyone should act and give her strength." He then calls for sovereignty using material resources and intellectual means, especially to uphold love for the motherland. By this, the landlord-town captain explains in Chapter viII that financial support from the rich and knowledge from the wise should be put together for a common cause. The lawyer-character of Oscar warns about the present 
republic imposed by the Americans, as well as the two-faced natives who disguise themselves as patriots but act as traitors.

Ruben, as the governor-aspirant, speaks on point as he appeals for total liberation from US rule. He seeks good governance that should be run by homegrown officials whose main motive is service and people's welfare. His audience had seen the tyranny of Spain and were now living witnesses to the present rule not exclusively from the Americans but also from the ill-suited local officials. Along with his father's perception of the land, Ruben sees the country as mercilessly exploited, deplorable, and hopeless, needing to be rescued through unity among the natives.

The novel's rise to popularity warranted another two volumes from Tolentino. The second and third volumes expose the ultimate betrayal of Don Luis's adopted son-nephew Gerardo by conniving with bandits to abduct and murder his cousin Ruben, Don Luis's only son. Though gnawed slightly by conscience, Gerardo employs tactics to cause misery to the family who trusts him most. Readers would associate him with the United States, whose act of support for the land had been a prelude to another invasion. The authorial eloquence of Tolentino is a scheme that was able to instruct his readers on the protocol of the justice system of his time. The author had to lead his readers that injustice prevails in the land. His voice is heard: "If Ruben would be found guilty despite his innocence then the whole government with its justice system should be guillotined."

The locals are vindicated when the American lawyer of Gerardo is defeated by Atty. Oscar, who defends his best friend, Ruben. This happens all the more when the audience in the courtroom, upon seeing Gerardo guilty, attacks him physically, prompting him to ask for immediate execution. Ruben is acquitted and Gerardo convicted. Tolentino was very successful in immersing his readers in his narratives, simultaneously instructing them to fight for their rights.

\subsubsection{Maring (1913)}

The story of Maring, subtitled Honor and Strength, is, again, a story of survival and sovereignty. Tolentino's message is cloaked in the strong-willed female character who can overcome all adversity that confronts her. She is tagged by Tolentino as "a hawk masked as a dove" and a "heart-strong" woman. The use of this metaphor to describe Maring not only empowers women of his time but connects her with the motherland. The country has seen multiple generations of colonial subversion, and just like Maring, she needs to come up strong and fighting. In the book's epilogue, the author emphasizes that his works are fruits of a long labor, a product of his detentions in his warfare against Spain and the United States, and also a manifestation of his quest for justice for the 
motherland. His readers were preconditioned to think that the novel speaks of a commendable woman whose hardships will be rewarded.

Local color is woven into the novel by Tolentino to include his readers in their present situation. Maring and her caring parents live in a simple and humble community. Townspeople happily dwell amid poverty and respect each other despite the presence of the Americans. When Maring is burdened with a sick husband and two children, she works as a housemaid to an American woman from 6:00 a.m. to 8:00 p.m. and is paid only PHP 8.00 monthly, lower than the usual worker's salary. She never complains, but her character is revealed when she fights for her dignity as a woman. She brawls with all her might when an American guest of her employer attempts to sexually abuse her. She strikes the bully using the ever-ready knife in her pocket. She does not hesitate to challenge and face the wrath of the Americans in doing so. In the same manner, Maring hits the wealthy Spaniard who tries tricking her into his bed. She tries shouting for help, but none comes. Tolentino's readers knew the reality and got his message.

Maring lives in poverty, doing odd jobs to support her two children but determined to be free from oppression. She is deceived and taken advantage of by more powerful people in her land. This does not deter her but rather encourages her further to escape from any trap. In the end, she receives the PHP 2,000.0O reward money for a wanted bandit that she overpowers. True, she suffers through a long series of trials and misfortune, but her willpower and resolve to emerge triumphant give readers a renewed optimism. The author is clear on his intent that the present situation is just temporary-that colonial rule will end, that there is a way to get out of the situation, and that, like Maring in the novel, the Filipinos will gain their reward of sovereignty.

\subsubsection{Kahapon, Ngayon at Bukas (1913)}

Tolentino's versified novel is undoubtedly a representation of his activism for the people's survival against the existing forces that dominated the land. Its English translation Yesterday, Today and Tomorrow, subtitled Reflection of the Land, easily jolts his audience into an awareness of the actual dilemma that the nation was facing. The author does not have any qualms about portraying the US government as the deceitful Haring Samuel who has offered goodwill but later takes possession of the land. The symbolic names of his characters are patently plain to every reader: the land's ruler Raha Lakhang Bayan (Motherland), his wife, Kalayaan (Freedom), his daughter, Mithi (Wish), and his trusted friend and savior, Haring Samuel (the United States). The author knew that through his verses, his readers would relate to his narrative. Tolentino's use of Haring Samuel's tactics to overpower Raha Lakhang Bayan's forces could 
easily connect to how the United States, presenting its goodwill to liberate the country from Spain, had vanquished the newly liberated Philippines during the 1898-1900 revolution. Aside from the appeal of the novel written in verse, the author stresses the stark reality of his time- the tyranny of the new foreign lords, the betrayal of the natives for their gain, and the helpless masses that could only hope for a better life.

The issue of survival explored in the novel focuses on the degree of treason that the new colonizers inflict on the naïve yet overly grateful natives. The narrative illustrates vividly how the imperialists take control of the land and change the usually placid and peaceful way of life through their modernization policy, but what is worse is the deteriorating life that the natives experience. The work further exposes that the new colonial lords benefit massively from the land's resources as they impose huge taxes and exploit the wealth of the land. Of the US construction and industrialization works, Kalayaan asks: "How much do we owe you?' Haring Samuel replies: 'You don't owe me anything, everything was built from your resources." Kalayaan continually cries: "Free us and let us rule our land," but her pleading is met with Samuel's "that cannot be, you are incapable of doing so....you are bereft of strength and intellect." The dismaying verses in the novel are heartfelt sentiments of the author himself.

The issue of sovereignty is thoroughly addressed to all sectors of society. The novel is well endowed with details on how to gain independence through unity and love for the motherland. Most dominant is a change of attitude toward the natives. Tolentino courageously tags local elite traitors as "worthless beasts" that are a dishonor to the country. The author attacks the inactive and unambitious peasants who do nothing to escape from poverty, hence remaining unproductive. Through the novel, Tolentino cries for a supreme effort for conversion in attitude to win sovereignty. He calls on his people to assert their rights, serve selflessly, be honest, think of others, show total allegiance to the motherland, and renounce loyalty to the present rulers, all uniting to prove that the natives are one race seeking total independence from foreign rule. Tolentino's novel ends with his utopian vision: the motherland gains total independence from US rule.

\subsubsection{Kasulatang Ginto (1914)}

Kasulatang Ginto (Golden Inscription), subtitled History of a Free Nation, greatly exhibits the call for survival and sovereignty that foretold the realization of total liberation. It is set in 1350 when gold abounded in the land. Diamonds, gold, and precious stones were an ordinary sight to every kingdom, but rulers and their people wanted everything for themselves. As recurrent in Tolentino's novels, his characters are giveaways of his message to readers: there 
should be unity to gain independence. Tolentino's use of symbolic names of his characters continued in this novel.

Bagong Araw, literally meaning New Day / New Sun, has been betrothed since birth to Tatlong Bituin (Three Stars) through a blood compact between the former's mother, Queen Liwayway (Dawn), and the latter's grandfather, King Sinukuan, the legendary king of the Kapampangan empire. The symbolism of the sun is attributed to the sun in the Philippine flag, which represents liberty, and the three stars, similar to the flag's elements, easily refer to the three big islands in the country. Hence, the characters themselves represent the author's call for freedom and the unity of divided islands.

The queen and king of separate kingdoms envision stopping the disputes among the divided territories and unite their people through the marriage of Bagong Araw and Tatlong Bituin. Their agreement is further sealed by the golden inscription intended to expose the real identity of her heir to the throne, Bagong Bayan.

Tolentino's discourse condemns local disputes, which are worse than fighting foreign aggressors. Maliwat stages a war against his father-in-law Makapagal and orders him killed to seize his throne. Countless people are sacrificed to satisfy the thirst and hunger for power of the ambitious Maliwat, who goes so far as to see his wife die in misery because of his betrayal. Conquerors, local or otherwise, have no place in a land inhabited by free people, so the author is quick to assure his readers that freedom shall be regained. Tolentino's authorial voice was heard clearly by his readers. They knew that evil deeds are punished, conquerors will cease to reign, and a united race triumphs in the end. True enough, Maliwat is subdued, and Bagong Hari regains his right to the throne and marries Tatlong Bituin. Finally, the divided nation has united, gained its freedom, and lives peacefully with its righteous ruler.

\section{Summary and Conclusion}

The novels speak of the cultural conditions that were borne by early 2oth-century Filipinos. The new American colonial lords wisely acknowledged that the three-century imprint of Spain needed to be wiped out from the natives. This was accomplished initially by a conversion from the Hispanicsubjective religious writings and fantasy tales into the promotion of the realism movement in literature that had become popular in American literature. The emergence of printing presses initiated by the American regime gave rise to multiple literary publications and organizations that local writers opted to take advantage of. Thousands of books, pamphlets, essays, poems, and orations 
have been printed during the first decades of the American era (Alip 1931, 104). Local writers who used to thrive on corridos decided to spurn and replace them, along with other Spanish-inspired literature, with true-to-life texts. Thus, the realistic type of literature was established and found to be more relevant to contemporary situations and welcomed by a growing number of readers. The latest backdrop meets the modern trend imposed by the new imperialists.

Furthermore, the sudden swing in the socioeconomic conditions prompted Aurelio Tolentino to settle for a more profitable genre of writing. The unexpected acceptance of the novel genre in the literary landscape of the province had to be acknowledged by the author. He could write in all disciplines-moralistic, poetic, political, philosophical, and journalistic. All these were infused in his novels to satisfy his financial needs and, as a primary aim, to get emotionally connected with his readers. Tolentino's migration to the central government not only exposed him to the publishing business but also asserted the exigency for him to produce more of his novels. He was first well known as a vernacular writer, but had to cater to his prospective Tagalog-speaking audience, the result of which could be seen as a fusion of Tagalog and Kapampangan languages. The author's struggle proves that more than his financial necessity as a new family man, his works of fiction were a means to an end.

Aurelio Tolentino's century-old novels are all explorations of the need for survival and his call for sovereignty. These works portray the need to survive both on the twofold standards of the locals and the immediate transformation of the society caused by the US liberalization policy. As represented by his novels, people are supposed to be free but are held captive not only by the invaders but also by the disunited character of the locals. The author's plea for sovereignty continues from the three-century rigid Spanish rule to the subsequent dynamism of US imperialism. The characters in the novels are depictions that persistently advocate to observe and endure the present situation yet constantly strive to attain complete independence from foreign intrusion. A firm voice is heard in the novels asserting unity and loyalty to the motherland.

\section{References}

Alip, Eufronio. 1931. Tagalog Literature (A Historico-Critical Study). Manila: Ust Press. Baldoz, Rick, and Cesar Ayala. 2013. "The Bordering of America: Colonialism and Citizenship in the Philippines and Puerto Rico." Centro Journal 25(1) (Spring): 76-102.

Department of Education. n.d. "K to 12." Department of Education. Accessed on April 18, 2018. https://www.deped.gov.ph/k-to-12/. 
Department of Education. n.d. "Senior High School Core Curriculum Classes." Department of Education. Accessed on May 12, 2020. https:/www.deped.gov.ph/ k-to-12/about/k-to-12-basic-education-curriculum/senior-high-school-corecurriculum-subjects/.

Ehrman, Bart D. 2014. “The Socio-Historical Method." The Bart Ehrman Blog: The History \& Literature of Early Christianity. Accessed on May 14, 2020. https:// ehrmanblog.org/the-socio-historical-method/.

Gamalinda, Eric. 200o. My Sad Republic. Philippine Centennial Commission

Garcia, Loida L. 2017. "The Hispanic Culture of Kapampangan Novels during the Age of US Imperialism." Research Journal of English Language and Literature 5(4): 53-8.

Lalas-Garcia, Loida. 2018. Sources and Influences of the 2oth century Kapampangan Novels. Glienicke: Galda-Verlag.

Larkin, John A. 1972. The Pampangans. Quezon City: New Day Publishers.

National Historical Commission of the Philippines. 2017. "15oth birth anniversary of Aurelio Tolentino." Accessed on May 6, 2020. http://nhcp.gov.ph/15oth-birthanniversary-aurelio-tolentino/.

Ocampo, Ambeth R. 2019. "Aurelio Tolentino's Handwritten Autobiography." Inquirer.net, September 20, 2019. https://opinion.inquirer.net/124083/aurelio-tolentinoshandwritten-autobiography.

Patterson, Christopher B. 2014. "The Filipino American in Spaces of Liberal Tolerance: Satire and Reciprocity in Peter Bacho's Cebu." Melus 39(1) (Spring): 149-51.

Reyes, Soledad. 1992. Kritisismo. Anvil Publishing.

Stuart-Santiago, Angela. 200o. "Book Review: My Sad Republic by Eric Gamalinda." The StuartXchange Book Reviews. http://www.stuartxchange.org/BookReview3.html.

Soto 2011. Lidia [microform]: Soto, Juan Crisostomo: Free Download, Borrow, and Streaming. 2011. Internet Archive. December 21. Accessed on July 15, 2021. https:// archive.org/details/apz7294.00o1.oo1.umich.edu.

Tolentino. 1913. Kahapon, Ngayon at Bukas (Larawan ng Bayan). Maynila: Limbagang Tolentino.

Tolentino, Aurelio. 19og. Buhay. Maynila: Limbagan ni Juan Fajardo.

Tolentino, Aurelio. 1913. Kasulatang Ginto. Maynila: Limbagang Noli.

Tolentino, Aurelio. 1913. Maring. Maynila: Limbagang Tolentino.

Tolentino, Aurelio. 1914. Ang buhok ni Ester. Maynila: Limbagang Noli. http://name. umdl.umich.edu/apuo970.0001.001.

Watt, Ian. 1957. The Rise of the Novel. Penguin Books. 